\title{
Динамика видового состава патогенов картофеля в европейской части РФ
}

\section{А.Н. Игнатов, Ю.С. Панычева, М.В. Воронина, Д.М. Васильев, Ф.С.-У. Джалилов}

Картофель находится на четвертом месте среди продовольственных культур в мире, и является одним из основных продуктов питания населения России. Высокая заболеваемость картофеля вирусными, бактериальными, оомицетными и грибными болезнями серьезно влияет на урожайность культуры, приводя также к экономическим потерям из-за выбраковки семенного картофеля и увеличения потерь при хранении. В последние годы отмечается рост вредоносности заболеваний картофеля, связываемый с климатическими изменениями, изменениями в популяциях патогенов, сменой выращиваемых сортов картофеля и других поражаемых патогенами растений. Эффект глобального потепления ожидается негативным - повышенная температура снижает скорость роста и накопление крахмала клубнями, вызывает физиологические повреждения и увеличивает восприимчивость к патогенам, ведет к росту популяции патогенов и их переносчиков. Оценивается, что при прогнозируемом повышении температуры, урожай картофеля на существующих площадях под этой культурой в мире упадет к 2050 году примерно на 14\%, значительная доля этих потерь в России будет вызвана новыми видами и биотипами патогенов картофеля. Оценка влияния изменения климата на фитофтороз картофеля, показала, что при росте средней температуры на $1{ }^{\circ} \mathrm{C}$, период применения фунгицидов для защиты картофеля удлиняется на 10-20 дней, в зависимости от количества осадков, а без защиты, потери урожая возрастут на 2 т/га на каждый градус потепления. Высокую опасность представляют возбудители антракноза, серебристой парши и ризоктониоза картофеля, штаммы которых выработали устойчивость к фунгицидам, применяемым для предпосадочной обработки клубней. Встречаемость и развитие комплекса патогенов, вызывающих бактериозы картофеля, постепенно нарастает, и кроме того, происходит постоянное изменение видового состава патогенов. В 2009 году было отмечено массовое распространение на картофеле видов Dickeya spp., а с 2012 года в России отмечают новые разновидности возбудителей черной ножки и мокрой гнили - P. carotovorum subsp. brasiliense; $P$. carotovorum subsp. odoriferum, и $P$. parmentieri. Природные факторы накладываются на недостатки агротехники и схем защиты картофеля, которые оказываются слишком консервативными для противодействия изменениям в составе и поведении фитопатогенов.

Ключевые слова: фитопатогены, картофель, климат.

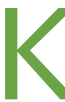

артофель (Solanum tuberosum

L.) занимает четвертое мес-

то среди продовольственных культур в мире, и его значение возросло за последнее десятилетие [1]. Картофель - один из основных продуктов питания населения России, эта культура характеризуется высокой продуктивностью в разнообразных климатических зонах, но он так же относится к числу наиболее поражаемых болезнями культур. Ежегодные потери урожая от фитопатогенов оценивают- alternata [3]. Преобладающие возбудители болезней подземной части растений - Rhizoctonia solani (ризоктониоз), Helminthosporium solani (серебристая парша), Spongospora subterranea f.sp. subterranea (порошистая парша), Fusarium spp. (фузариозное увядание), Verticillium dahliae и V. albo-atrum (вертициллезное увядание) [4]. Среди бактериальных заболеваний наиболее распространены черная ножка и мокрая гниль, вызываемые видами Pectobacterium spp. (P. carotovorum, $P$. atrosepticum, $P$. parmentieri, $P$. polaris, $P$. aroidearum, $P$. peruviense, $P$. polonicum, $P$. punjabense, Cand. $P$. maceratum) и подвидами $P$. carotovorum ( $P$. carotovorum subsp. brasiliense, $P$. carotovorum subsp. carotovorum, P. carotovorum subsp. odoriferum), видами Dickeya spp. (D. solani, D. diantyhicola) и Pseudomonas marginalis [5].

Наибольшую тревогу вызывает распространение возбудителя кольцевой гнили картофеля Clavibacter michiganensis susp. sepedonicus, входящего в списки карантинных объектов Европейского Союза и многих других стран, и картофельной расы возбудителя бактериального рака C. michiganensis subsp. michiganensis, поражающей также и томат в открытом и защищенном грунте, что создает перманентные очаги заражения для пасленовых культур.

Картофель поражается многими вирусами, многие из которых наиболее вредоносен вирус игрек (Potato Virus Y (PVY)) и ряд других вирусов (PVA, PVL, PVM, PVS, PLRV), переносимые насекомыми (Aphididae и другие) и механически, или только механически (PVX) [6].

В последние годы отмечается рост вредоносности заболеваний картофеля, связываемый с климатическими изменениями, изменениями в популяциях патогенов, сменой выращиваемых сортов картофе- 
ля и других поражаемых патогенами растений. Согласно прогнозу межправительственной группы экспертов по климату [7], средняя годовая температура к 2100 году возрастет на 1,4-3 ${ }^{\circ} \mathrm{C}$ выше значения 1990 года. Эффект глобального потепления в картофелеводстве скорее всего будет негативным - температура выше $30{ }^{\circ} \mathrm{C}$ снижает скорость роста и накопление крахмала клубнями, вызывает физиологические повреждения и увеличивает восприимчивость к патогенам. Оценивается, что при прогнозируемом повышении температуры, урожай картофеля на существующих площадях под этой культурой в мире упадет к 2050 году примерно на 14\% [8].

\section{Фитофтороз картофеля}

Фитофтороз картофеля - наиболее вредоносное заболевание этой культуры. Отмечено, что рост экономических потерь от этой болезни происходит уже 30 лет по всему миру [3, 4]. Это может быть вызвано распространением новых популяций, сочетающих типы спаривания А1 и А2, что позволяет образовывать ооспоры после полового процесса, и адаптироваться к новым климатическим условиям и новым устойчивым сортам картофеля и томата. Проведенный в 2009-2017 годах мониторинг популяций возбудителя фитофтороза в основном из Московской области РФ показал, что средние частоты присутствия типов спаривания A1 и A2 в картофельной субпопуляции составляли 40,5 и 59,5\% соответственно. До 2008 года в России доминировали изоляты A1 типа, и соответственно, адаптация патогена к новым условиям, устойчивым сортам и фунгицидам проходила медленнее [9]. В составе генов вирулентности изученной популяции возбудителя фитофтороза почти постоянно присутствовали все 11 известных генов. Согласно данным многолетним наблюдениям, в России сложные «суперрасы» патогена, содержащие 7-11 генов вирулентности, встречаются на картофеле, причем в Московской области доля таких патотипов может достигать 50$70 \%$ [20], а иногда даже 100\% [10]. Усредненная за 2009-2017 годы частота встречаемости металаксил-устойчивого фенотипа в картофельной субпопуляции патогена составляла 17,1\% (включая среднеустойчивые фенотипы) [11], что резко снижает эффективность фунгицидной защиты от болезни.
Оценка влияния изменения климата, проведенная в многолетних экспериментах, показала, что при росте средней температуры на $1{ }^{\circ} \mathrm{C}$, период применения фунгицидов для защиты картофеля от фитофтороза удлиняется на 10-20 дней, в зависимости от количества осадков, а в случае несостоявшейся защиты (например, из-за резистентности патогена), потери возрастут на 2 т/га на каждый градус потепления [12].

\section{Альтернариоз и другие грибные болезни}

Ранняя сухая пятнистость или ранний ожог картофеля (A. solani и $A$. alternata) поражает растения в начале лета, при сочетании высокой влажности воздуха, наличия капельножидкой влаги на поверхности листьев и температуры в диапазоне от $10{ }^{\circ} \mathrm{C}$ (минимальная) до $35^{\circ} \mathrm{C}$ (максимальная), с оптимумом около $25{ }^{\circ} \mathrm{C}$ [13]. Распространение спор патогенов происходит наиболее активно в периоды между увлажнением листьев [13, 14].

Оценивая распределение двух основных видов Alternaria spp., поражающих картофель на европейской части РФ, А. Белосохов с коллегами [15] отметили преобладание $A$. solani в умеренной климатической зоне и доминирование $A$. alternata на юге России. Значительная часть изученных образцов была поражена комплексом $A$. solani и $A$. alternata. Анализируя собственные экспериментальные данные и ранее опубликованные результаты исследований, можно сказать, что существующий географический тренд на постепенное вытеснение $A$. solani при повышении средней температуры прослеживается и во времени в связи с климатическими изменениями на территории европейской части РФ.

Около четверти образцов картофеля с похожими на ранний ожог симптомами были поражены другими грибными патогенами - Cladosporium sp. Colletotrichum coccodes. В отличие от альтернаризоза, эти возбудители поражают также и стебель и способны вызывать быструю гибель всего растения $[15,16]$

Несовершенный гриб C. coccodes поражает не менее 35 растений-хозяев из 13 семейств. C. coccodes вызывает симптомы антракноза - появление язв на корнях, столонах,

стеблях, плодах. На клубнях картофеля он, как правило, вызывает симптомы серебристой парши, но отличается от Helminthosporium solani наличием мелких точечных черных склероциев на пораженных частях, в связи с чем это заболевание клубней называют «черная пятнистость» [17]. Пораженные клубни семенного картофеля являются важным фактором распространения возбудителя в новых регионах. В основном, зараженные этим патогены клубни отмечаются в партиях, импортированных из Западной Европы [17], но в последние годы, это заболевание массово распространилось в Северозападном регионе РФ.

Особую опасность представляют виды грибов Helminthosporium solani, Colletotrichum coccodes и Rhizoctonia solani, штаммы которых выработали устойчивость к фунгицидам, применяемым для предпосадочной обработки клубней [18].

Кроме указанных выше патогенов, часто встречаются партии картофеля с клубнями пораженными возбудителями фузариозного и вертицилезного увядания [19], распространяется в последние 5 лет ареал заболевания розовой (Phytophthora erythroseptica) и питиозной гнилью (Pythium ultimum) [20]. Нет данных по динамике развития фузариоза на картофеле в целом по стране, но, если интерпретировать изменения распространенности зараженности на других культурах, которая увеличилась в 2-2,5 раза за 10 лет, и достигла почти $100 \%$ в партиях картофеля в Поволжье в 2011 году, то очевидно, что фузариоз картофеля выходит в число основных проблем отрасли. Начало эпифитотии фузариозного увядания на картофеле в Татарстане связывают с распро-

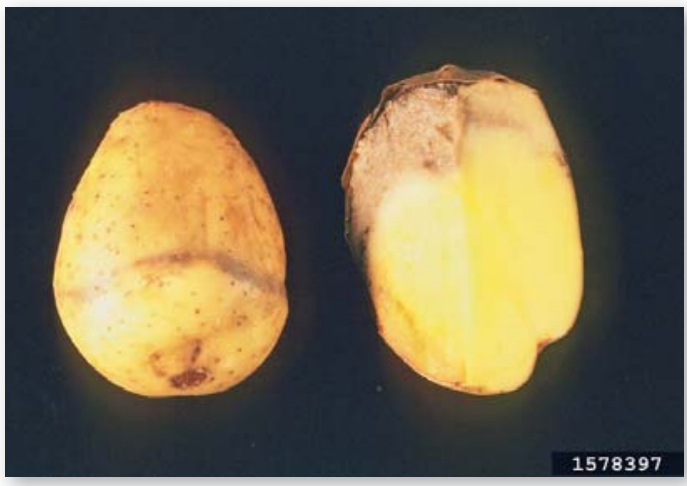

Мягкая гниль картофеля, возбудитель Pectobacterium carotovorum (использован с разрешения Bugwood.org, авторы: Gerald Holmes, California Polytechnic State University at San Luis Obispo) 


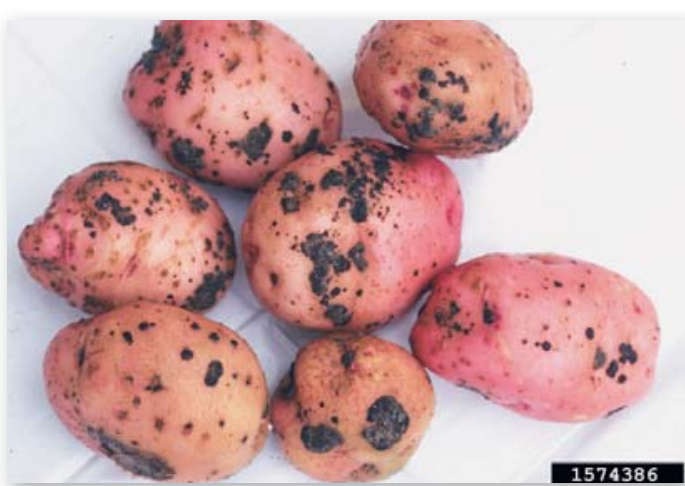

Ризоктониоз картофеля, возб. Rhizoctonia solani (использован с разрешения Bugwood.org, автор: William M. Brown Jr)

странение заражения в поле в условиях 2011 году. Распространенность фузариоза в скрытой форме на семенном картофеле сортов, выращенных в Поволжье, составляла в феврале 2014 года в среднем 15$20 \%$ [21]. По данным авторов, посадочный материал картофеля большинства сортов, произведенные в 2017 году в Московском регионе, также имели от 5 до 15\% клубней со скрытым или явным заражением. Сравнивая распространение фузариоза на различных культурах, можно отметить постоянное продвижение наиболее агрессивных форм патогенов этого рода на север.

Черная ножка и мокрая гниль картофеля

Встречаемость и развитие комплекса патогенов, вызывающих бактериозы картофеля, постепенно нарастает, и кроме того, происходит постоянное изменение видового состава патогенов. Еще 10-15 лет назад, главной причиной заболевания растений черной ножкой считали вид Pectobacterium atrosepticum, а мокрую гниль в поле и в период хранения вызывал $P$. carotovorum, иногда поражение растений связывали с развитием Pseudomonas marginalis [5]. Отчасти благодаря изменению климата, отчасти изза проникновения в Россию новых видов возбудителей, в последнее десятилетие произошли значительные изменения видового состава этих патогенов. В 20092013 годах было отмечено массовое распространение на картофеле видов Dickeya spp. (D. Solani, D. dianthicola) [22], которые стали причиной серьезных потерь урожая картофеля в Российской Федерации. Главное отличие бактерий рода Dickeya от обычных возбудителей черной ножки картофеля - большая агрессивность при повышенной температуре.

В 2013 году была отмечена максимальная распространенность возбудителей рода Dickeya в зараженных партиях семенного картофеля в России - до 26-28\% [23] при оценке ПЦР методом, или до 24,8\% при оценке ИФА [24]. Наиболее вероятной причиной проникновения патогенов рода Dickeya в РФ был завоз зараженного посадочного материала картофеля из стран Западной Европы [25], и при введении строгих мер контроля со стороны производителей, доля зараженных ими партий семян снизилась к 2017 году до 0,2-3\% [26, 27 , А. Игнатов, неопубликованные данные].

С 2012 года в России отмечают новые разновидности возбудителей черной ножки и мокрой гнили - $P$. carotovorum subsp. brasiliense; $P$. carotovorum subsp. odoriferum, и $P$. parmentieri) [27, 28]. Они принципиально не отличаются от $P$. carotovorum subsp. carotovorum или $P$. atrosepticum по своей агрессивности. Вероятно, их массовое распространение в РФ было связано с возросшим после 2014 года импортом картофеля, овощей и фруктов из субтропической зоны, где эти виды и подвиды поражают растения как в открытом, так и в защищенном грунте. Рост продолжительности периода с оптимальными для новых бактериальных патогенов температурами (29-34 $\left.{ }^{\circ} \mathrm{C}\right)$ приводит к увеличению частоты заражения растений в поле и степени развития болезней [5]

В 2011-2013 годах в Биоцентре ВНИИКХ было проведено 1420 экспертиз на выявление возбудителей бактериозов методом ИФА для партий семенных клубней из различных агроклиматических регионов РФ. Средние значения зараженности среди всех партий семян составили $35 \%$ для $P$. atrosepticum и 14\% для Dickeya spp. [24]. Сравнивая инфицированность партий семенного картофеля различных категорий, было показано, что при уровне зараженности внутри партий оригинального семенного материала не превышающим 15\%, следующее поколение этих же семян было пораженным уже на 30\% [24].

Озабоченность вызывает распространение кольцевой гнили, вызываемой Clavibacter michiganensis susp. sepedonicus. Результаты оценки зараженности партий картофеля зарубежного происхождения показывают присутствие патогена в 6,5\% случаев, в то же время инфицированность отечественных партий картофеля в 2011-2013 годах составила 32,8\% [24]. В некоторых регионах России частота встречаемости зараженных партий картофеля достигает 60\%, и отмечается рост зараженности картофеля внутри партий [29].

\section{Вирусы}

Среди вирусов картофеля, наибольшее внимание уделяют вирусу Y (PVY) и вирусу скручиваемости листьев картофеля (PLRV). PVY наиболее распространен не только в РФ, но и во всем мире, и при заражении совместно с другими вирусами (PVS, PVM, PVA, PVX, PVL), потери урожая могут превысить $80 \%$. PLRV вызывает снижение урожайности на 20-70\% и, в отличие от других вирусов, является персистентным при переносе тлями. Для приобретения вируса тлям необходимо длительное питание на зараженном растении, и латентный период в теле насекомого, после которого вирофорные насекомые сохраняют способность к передаче вируса за счет его размножения в насекомых [30]. Заражение семян вирусами ведет к вырождению семенного материала, но существующий ГОСТ 33996-2016 (Картофель семенной. Технические условия и методы определения качества) допускает наличие в семенах элитной и последующих репродукций более 10\% зараженных PVY клубней, что приводит к почти 100\% перезаражению растений в поле [31].

Оценки общего распространения вирусных инфекций в РФ сильно различаются. Данные лабораторий Россельхозцентра за 201517 годы показывают, что наиболее часто выявляемыми оказались вирусы PVS - 46,2\% инфицированных образцов $(28,8 \%$ от общего числа проб, включавших 580 образцов зеленых растений и 456 образцов клубней), PVYo - 45,7\%, и PVM 34,7\%. PVX, PVYntn, PVA были найдены соответственно в $12,1 \%, 9,7 \%$, и $6,0 \%$ зараженных проб. PLRV и PMTV были обнаружены только в двух образцах каждый (1,2\% от общего числа инфицированных проб), причем исключительно в составе смешанных инфекций [24]. Вероятно, что низкий процент заражения был связан с преобладанием 
в анализе высоких репродукций семенного материала.

По данным диагностической лаборатории компании «Сингента» за 2014-2017 годы, доложенным в ежегодном отчете 13 января 2019 года, зараженность вирусами была обнаружена среди более 760 образцов семенного картофеля у $90 \%$ образцов элиты и последующих поколений в 2014 году, из них одиночными вирусами были поражены 13\%. В 2015-2017 годах уже 99-100\% партий картофеля имели зараженные клубни, причем, 97-99\% были инфицированы двумя и более вирусами. Среди вирусов доминировало заражение PVY (от 82\% в 2014 году до 98\% в 2016-2017 годах), на втором и третьем месте - PVS и PVM.

В качестве одного из факторов увеличения зараженности картофеля PVY можно назвать распространение толерантных к вирусу сортов, растения которых часто не диагностируются как зараженные при визуальной диагностике или методами ИФА на стадии клубней. Другой важный фактор - увеличение популяции переносчика вирусов картофеля - нескольких видов крылатой тли (Hemiptera: Aphididae) [6]. Но главное - рост средних температур, и особенно продолжительности периода, когда минимальные температуры превышают $16^{\circ} \mathrm{C}$, что обеспечивает системное заражение вирусами инфицированного растения

Оценка динамики ареалов, занимаемых беспозвоночными видами потенциальными переносчиками болезней растений, за 25 лет, показала, что 83,6\% из 275 видов продвинулись на север. При увеличении средних температур, особенно в зимний период, 5 из 8 видов изученных насекомых увеличили численность популяций [32]. Рост числа потенциальных переносчиков ведет к ускорению переноса вирусов картофеля в течении вегетационного сезона.

\section{Выводы}

Не вызывает сомнения то, что благодаря работе современных диагностических лабораторий, использующих методы ПЦР диагностики, нам удается впервые получать детальную информацию о видовом составе и распространенности патогенов картофеля. Фактически, для сравнения пригодны данные лишь за последние 4-8 лет, поскольку предыдущие результаты были получены при ис- следованиях ограниченного числа образцов или растений из отдельных регионов РФ. Но, при всех недостатках анализируемых данных, становится очевидным, что зараженность посадочного материала и распространение болезней картофеля в поле растут благодаря изменениям климата глобальному потеплению, увеличению безморозного периода, мягким зимам, экстремальным погодным событиям, переносящим возбудителей болезней на большие расстояния с воздушными массами [33], и общему распространению ареала фитопатогенов и их переносчиков на север и восток РФ [32]. Природные факторы накладываются на недостатки агротехники и схем защиты картофеля, которые оказываются слишком консервативными для противодействия изменениям в составе и поведении фитопатогенов.

\section{Библиографический список}

1.World Potato Statistics. (2018). The potato sector (FAOSTAT). http://www.potatopro.com/world/potatostatistics Дата обращения 20.07.2019.

2.Ахатов А. К. и др. Болезни и вредители овощных культур и картофеля. 2013. М.: КМК.

3.Van der Waals J.E. et al. Climate change and potato production in contrasting South African agro-ecosystems 3. Effects on relative development rates of selected pathogens and pests //Potato Research. 2013. Vol. 56. Pp. 67-84.

4.Denner F.D. et al. Guide to potato production in South Africa // Agricultural Research Council-Vegetable and Ornamental Plant Institute. 2012. Pretoria.

5.Pérombelon M.C.M. Potato diseases caused by soft rot erwinias: an overview of pathogenesis //Plant Pathol. 2002. Vol. 51. Pp. 1-12

6.Radcliffe E.B. Insect pests of potato. //Ann Rev Entomol 1982. Vol. 27. Pp. 173-204

7.Пачаури Р.К., Райзингер А. Изменение климата, 2007 г: Обобщающий доклад. Вклад рабочих групп I, II, III в Четвертый доклад об оценке Межправительственной группы экспертов по изменению климата // Межправительственная группа экспертов по изменению климата (МГЭИК). 2007. Женева, Швейцария. 105 с.

8.Jatav M.K. et al. Impact of Climate Change on Potato Production in India. // Sustainable Potato Production and the Impact of Climate Change. 2017. IGI Global. Pp. 87-104

9.Statsyuk N. et al. Long-term study of the Phytophthora infestans population from the Moscow region of Russia (2000-2011) // Proceedings of the 48th Croatian and 8th International Symposium on Agriculture. Osijek: University of Josip Juraj Strossmayer, 2013. Pp. 328-332.

10.Еланский С.Н. и др. Структура и динамика популяций Phytophthora infestans - возбудителя фитофтороза картофеля и томата // Защита картофеля. 2017. № 3. С. $3-44$.

11.Кузнецова М.А. и др. Мониторинг изолятов Phytophthora infestans, выделенных с картофеля и томатов в Московской области (2009-2017 гг.) // Достижения науки и техники АПК. 2018. Т. 32. № 3. С. 28-33.

12. Kaukoranta T. Impact of global warming on potato late blight: risk, yield loss and control //Agricultural and Food Science. 1996. Vol.5. Pp. 311-327

13.Bashi E, Rotem J. Adaptation of four pathogens to semi-arid habitats as conditioned by penetration rate and germinating spore survival // Phytopathology. 1974. Vol. 64. Pp. 1035-1039.

14.Van der Waals J.E. et al. Influence of environmental factors on field concentrations of Alternaria solani conidia above a South African potato crop // Phytoparasitica. 2003. Vol. 31. Pp. 353-364

15.Belosokhov A.F. et al. Alternaria spp. and Colletotrichum coccodes in potato leaves with early blight symptoms. PAGV-Special Report. 2017. Vol. 18. Pp. 181-90.

16.Johnson D.A. Effect of foliar infection caused by Colletotrichum coccodes on yield of Russet Burbank potato // Plant Disease. 1994. Vol. 78. Pp. 1075-1078

17.Кутузова И.А. Внутривидовая вариабельность фитопатогенных грибов Colletotrichum coccodes n Helminthosporium solani Автореферат дис. к.б.н. 2018. Москва. 25 сс.

18.Еланский С.Н. и др. Устойчивость Helminthosporium solani, Colletotrichum coccodes и Rhizoctonia solani $k$ фунгицидам, используемым для обработки клубней картофеля // Достижения науки и техники АПК. 2018. T. 32. C. $1-5$

19.Смирнов А.Н. и др. Пораженность семян зерновых культур и клубней картофеля грибными болезнями // Владимирский земледелец. 2015. №. 2. С. 24-27

20.Полинова А.И. и др. Биологические особенности Pythium ultimum Trow - возбудителя водянистой гнили клубней картофеля // Защита картофеля. 2017. №1. С. 35-38

21.Замалиева Ф.Ф. и др. Фузариозное увядание картофеля и рекомендации по защите // Защита картофеля. 2015. №2. С. 3-9.

22.Карлов A.Н. и др. Dickeya dianthicola - новый для России бактериальный патоген картофеля. // Известия TCXA. 2010. №3. С. 134-141.

23.Игнатов А.Н. и др. Распространение бактериальных и фитоплазменных болезней растений в России // Защита и карантин растений. 2015. №. 5. С. 6-9.

24.Зайцев И.А. и др. Мониторинг скрытых (латентных) форм распространения возбудителей черной ножки и кольцевой гнили картофеля в Российской Федерации // Сельскохозяйственные науки: научные приоритеты ученых. 2016. С. 38-55.

25.Игнатов А.Н. и др. Бактериозы картофеля в Российской Федерации // Картофель и овощи. 2018. № 1. С. 3-7.

26.Французов П.А. и др. Широкомасштабный скрининг РНК-и ДНК-содержащих патогенов картофеля при помощи ПЦР в матричном формате // Достижения науки и техники АПК. 2018. Т.32. С.1-10

27.Карандашов В. Pectobacterium carotovorum subsp. brasiliensis - основной бактериальный патоген картофеля осенью 2017 г. // URL: www.welikepotato. ru/ assets/files/present/ 123456/ pectobacteriumcarotovorum-subsp.-brasiliensis.pdf. Дата обращения: 09.08.2019.

28.Voronina M.V. et al. First report of Pectobacterium carotovorum subsp. brasiliense causing blackleg and stem rot disease of potato in Russia // Plant Disease. 2019. Vol.103. Pp.364

29.Зинников Д.Ф., Синкевич О.В. Кольцевая гниль картофеля - скрытая угроза урожаю // Карантин растений. Наука и практика. 2015. №. 13. С. 6-11

30.Sigvald $R$. The relative efficiency of some aphid species as vectors of potato virus Yo (PVo) // Potato Res 1984. Vo. 27. Pp. $285-290$

31.Панычева Ю.С. и др. Динамика поражения сортов картофеля вирусом Ү в полевых условиях // Картофель и овощи, 2019, № 5. С. 25-31

32.Мусолин Д.Л., Саулич А.Х. Реакции насекомых на современное изменение климата: от физиологии и поведения до смещения ареалов // Энтомологическое обозрение. 2012. Т. 91. С.3-5

33.Skelsey P. et al. Regional spore dispersal as a factor in disease risk warnings for potato late blight: a proof of concept // Agric. For Meteorol. 2009. Vo. 149. Pp. 419-430.

\section{Об авторах}

Игнатов Александр Николаевич (ответственный за переписку), док- 
тор биол. наук, зам. ген. директора по научной работе, ООО ИЦ «ФитоИнженерия», профессор, Аграрно-технологический институт Российский Университет Дружбы народов.

E-mail: a.ignatov@phytoengineering.ru Панычева Юлия Сергеевна, аспирант, ООО ИЦ «ФитоИнженерия», ФГБНУ «Всероссийский научно-исследовательский институт сельскохозяйственной биотехнологии

E-mail: j.panycheva@phytoengineering.ru

Воронина Майя Васильевна, канд. биол. наук, научный сотрудник, ООО ИЦ «ФитоИнженерия».

E-mail: m.voronina@phytoengineering.ru Васильев Дмитрий Михайлович, канд. биол. наук, научный сотрудник, ООО ИЦ «ФитоИнженерия».

E-mail: d.vasilev@phytoengineering.ru Джалилов Февзи Сеид-Умерович, доктор биол. наук, профессор, заведующий кафедрой защиты растений, ФГБОУ ВО Российский государственный аграрный университет - МСХА им. К.А. Тимирязева.

E-mail: labzara@mail.ru

Dynamics of species composition of potato pathogens in the European part of the Russian Federation

A.N. Ignatov (author for correspondence), $D S c$, Director on research R\&D Center
"PhytoEngenering" and professor, Agrotechnological Institute, Peoples ' friendship University of Russia.

E-mail: a.ignatov@phytoengineering.ru J.S. Panycheva, postgraduate student, R\&D Center "PhytoEngenering" and All-

Russian Research Institute of Agricultural Biotechnology.

E-mail: j.panycheva@phytoengineering.ru. M.V. Voronina, $P h D$, research fellow, R\&D Center "PhytoEngenering".

E-mail: m.voronina@phytoengineering.ru

D.M. Vasiliev, $P h D$, research fellow, $R \& D$

Center "PhytoEngenering".

E-mail: d.vasilev@phytoengineering.ru

F. S-U. Dzhalilov, DSc, professor, head of

Department of plant protection, Russian

State Agrarian University - Moscow

Agricultural Academy by K. A. Timiryazev.

E-mail: labzara@mail.ru

Summary. Potatoes are in the fourth place among the main food crops in the world, and is one of the main food products of Russia. High impact of potato viral, bacterial, oomycete and fungal diseases has a serious threat to crop yield, leading to economic losses due to culling of seed potatoes and increase storage losses. In recent years, there has been an increase in the harmfulness of potato diseases associated with climatic changes, changes in the populations of pathogens, the change in cultivated potato varieties and other host plants. The effect of global warming is expected to be negative - elevated tempera- tures reduce the growth rate and accumulation of starch by tubers, cause physiological damage and increase susceptibility to pathogens, increase the pathogens and their vectors propagation rate. It is estimated that with the projected increase of global temperature, the potato yield at the existing areas across the World will fall by 2050 for about 14\%, a significant proportion of these losses in Russia will be caused by new species and biotypes of potato pathogens. Estimated global warming effect proved that average temperature growth for each $1^{\circ} \mathrm{C}$ will elongate the necessary fungicide application period against Phytophthora infestance for 10-20 days depending to rains amount. Lack of protection will cause an additional yield loss of $2 t /$ ha for each degree of warming. There is a high risk of fungicide-resistant plant pathogens causing potato anthracnose, Rhizoctonia canker or black scurf, and silver scurf. Occurrence and harm of bacterial plant pathogens of potato is increasing and species prevalence is changing. Dickeya species became common potato pathogen in Russia at 2009, but since 2012 they there substituted by new Pectobacterium subspecies $P$. carotovorum subsp. brasiliense; $P$. carotovorum subsp. odoriferum, and species $P$. parmentieri. Environmental factors underline and multiply the errors in agro-technique and plant protection of potato, which are too conservative to withstand the changes in content and life style of plant pathogens.

Keywords: plant pathogens, potato, climate.

\section{Красноярский край стал лидером по производству овощей в Сибири}

В Сибирском федеральном округе провели совещание по вопросам развития овощеводства

В Красноярском крае увеличилось производство и урожайность овощей. В сравнении с 2017 годом сбор овощей вырос на $12 \%$ и составил 164 тыс. т при урожайности 26 т/га. На сегодняшний день Красноярский край является лидером в Сибирском федеральном округе по производству овощей. Об этом на семинаре-совещании по вопросам развития овощеводства сообщил заместитель министра сельского хозяйства и торговли региона Сергей Брылев.

Совещание состоялось в Шушенском районе на базе местного овощного госсортоучастка. Специалисты предприятия рассказали участникам о высокоурожайных и высокотоварных сортах и гибридах овощных культур и картофеля, внесенных в Госреестр и допущенных к использованию на территории края, о технологиях их возделывания. Специалисты также продемонстрировали посевы и продукцию Шушенского сортоучастка, предложили продегустировать овощи и картофель, выращенные на полях предприятия.

Заместитель министра сельского хозяйства и торговли края Сергей Брылев отметил необходимость соблюдать технологии производства, подбирать адаптированные к природно-климатическим условиям региона сорта и гибриды, повышать эффективность использования посевного гектара за счет роста урожайности и товарности с.-х. культур.

- Около 80\% овощных культур в регионе выращивает население, поэтому нашим с.-х. предприятиям есть куда расти в этом направлении, - подчеркнул замминистра. - Регион на первом месте среди субъектов Сибирского федерального округа по производству овощей, но все же обеспеченность ими на душу населения в крае составляет сейчас $47 \%$. Наша задача - достичь $70 \%$. Есть потребность в качественных семенах, дающих гарантированный рост урожайности на 25-30\%.

Сегодня уборку овощей ведут аграрии Березовского, Сухобузимского, Енисейского и Шушенского районов. Получено 275 т овощей, урожайность составила 29,6 т/га. В Красноярском крае овощи выращивают 68 с.-х. организаций (в прошлом году было 62). В числе лидеров по сбору овощей глава КФХ Велькер А.А. из Березовского района, а также ООО «Искра» Рыбинского района и ООО СХП «Дары Малиновки» Сухобузимского района. По урожайности лидируют ИП Светлолобов Н.Б. из Шушенского района, ООО «Искра» Рыбинского района, глава КФХ Вензель А.А. и СПК «Аленушка» из Березовского района. 